\title{
Temizlik İşleri Çalışmalarında Risk Değerlendirmesi: Alanya Belediyesi Örneği
}

\author{
DOI: $10.26466 /$ opus. 917527
}

\author{
Adem Demir * Mehmet Gümüş ** - Hacer Yumurtacı Aydoğmuș ${ }^{* * *}$ - Eren Kamber ${ }^{* * * *}$ \\ * Alanya Belediyesi, Temizlik İşleri Müdürü, Antalya/Türkiye \\ E-Posta: ademdemir@alanya.bel.tr $\quad$ ORCID: $\quad \underline{\text { 0000-0002-7569-2107 }}$ \\ ** Prof. Dr., Alanya Alaaddin Keykubat Üniversitesi, Antalya/Türkiye \\ E-Posta: mehmet.gumus@alanya.edu.tr ORCID: $\quad$ 0000-0003-2588-0270 \\ *** Dr. Öğr. Üyesi, Alanya Alaaddin Keykubat Üniversitesi, Antalya/Türkiye \\ E-Posta: hacer.aydogmus@alanya.edu.tr $\quad$ ORCID: $\quad \underline{\text { 0000-0002-2307-0840 }}$ \\ **** Arş. Gör., Alanya Alaaddin Keykubat Üniversitesi, Antalya/Türkiye \\ E-Posta: eren.kamber@alanya.edu.tr ORCID: 0000-0002-6426-9936
}

Öz

Nüfusun artması ve bilinçlenmesi ile belediyeler hizmet alanların genişletmişlerdir. Bu hizmet alanları içinde temizlik işleri çalışmaları ve çalışma alanları gittikçe daha önemli bir yere sahip olmuştur. Çalışma alanlarının artması ve yeni bir takım makinelerin kullanılmaya başlanması ile iş sağlığı ve güvenliğine verilen önem ve değer de artmıştır. Bu araştırmanın amacı yerel yönetimlerce işletilen temizlik işlerinin çalışma alanlarındaki karşılaşabilecekleri tehlike ve risklerin belirlenmesidir. Araştırma yapılırken saha çalışmaları ve bütün bölümler incelenmiştir. İncelenen kısımlarda; ne gibi tehlikeler olabileceği bu tehlikeler karşısında alınabilecek önlemeler, tehlike kaynağı yok edilemiyor ise en aza nasıl indirgenebileceği tespit edilmiştir. Bu incelemeler sonucunda yasal mevzuat temel alınmış olup önerilerde bulunulmuştur. Hazırlanmış olan risk değerlendirme tablosunda L Tipi Matris yöntemi kullanılmıştır. Bu araştırma kapsamında çalışanların karşılaşabilecekleri fiziksel, kimyasal, ergonomik, mekanik, psikososyal risk faktörleri çalışma alanlarında gözlemlenerek tespit edilmeye çalışılmıştır. Çalışma koşullarını iyileştirmeye ve sağlık düzeylerini geliştirmeye yönelik önerilerde bulunulmuştur. Sunulan risk analizi raporu iş sağhlğı ve güvenliği çalışmalarına katkı sağlamıştır.

Anahtar Kelimeler: Belediyecilik, Yerel Yönetim, Temizlik Işleri Çalışanları Güvenliği. 


\title{
Risk Assessment in Cleaning Works: The Example of Alanya Municipality
}

\begin{abstract}
Municipalities have expanded their service areas with the increase of the population and their awareness. Among these service areas, Cleaning Services Works and their working areas have taken a more important place. The importance and value given to Occupational Health and Safety have also increased with an increase in the working areas and the initiation of a new set of machines to be used. The purpose of this research is to determine the dangers and risks that may be encountered in the working areas of cleaning works operated by local administrations. While doing the research, field studies and all departments were examined. In the examined parts; what kind of dangers there may be, the precautions that can be taken against these dangers, and how to minimize the danger source if the source of danger cannot be eliminated has been determined. As a result of these examinations, the legal legislation was taken as a basis and recommendations were made. L Type Matrix method was used in the risk assessment table prepared. This study covered employees who may face physical, chemical, ergonomic, mechanical, psycho-social risk factors that have been studied to be determined by observing in the work area. Suggestions were made to improve working conditions and health levels. The Risk analysis report submitted has contributed to occupational Occupational Health and Safety studies.
\end{abstract}

Key Words: Municipal Administration, Local Administration, Cleaning Workers Safety. 


\section{Giriş}

Temizlik sektörü; genel anlamda incelendiğinde, bütün endüstriyel iş kollarında, kapalı ve açık mekanlarda, kamusal alanlarda ve özel işletmelerde faaliyet göstermekte olan hizmet sektörünün ana bileşenlerindendir (Brun, 2009, s.9). Temizlik işleri kavramı, süpürmekten başlayarak atıkların yok edilmesine kadar süren süreci göstermektedir. Kapsam olarak ise, ev, ofis, işyerleri, okullar, mağazalar, araçlar veya hastaneler gibi birbirinden oldukça farklı özelliklerdeki çalışma ortamlarında yapılmaktadır. Temizlik işlerinde çalışanların içinde bulunduğu riskler sadece yaptıkları temizlik işi ile sınırlı değildir. Aynı zamanda, çalıştıklar1 sektör ve işyerlerine göre de işin riski değişmektedir (Zock, 2005, s.581).

Temizlik faaliyetleri toplum için hayati önem taşmakta ve dünya çapında milyonlarca insan temizlik sektöründe çalışmaktadır. Temizlik ve Destek Hizmetleri Derneği'nin 2002 yılı verilerine göre İngiltere'de yaklaşık 800.000 kişi temizlikçi olarak çalışmaktadır. Bu iş gücünün boyutu göz önüne alındığında, üstlenilen fiziksel olarak zorlu işler ve temizlikçilerin faaliyet gösterdiği çeşitli ortamlarda, çalışanların sağlıklı kalmasını ve işi tatmin edici bir standartta tamamlamasını sağlamak için güvenli çalışma uygulamaları yürürlükte olmalıdır (Woods ve Buckle, 2006, s.61).

Günümüze gelindiğinde artan nüfus yoğunluğu ve çalışma alanının artması temizlik işlerinde iş kazası ve ramak kala olaylarında doğru orantılı arttığını göstermektedir. Temizlik işlerinde çalışan personelin bu yoğunluktan dolayı çeşitli risk kaynakları ile karşılaştığı görülmektedir.

İş sağlığı ve güvenliği konuları kapsamında iş kazaları önemli bir yer tutmaktadır. İş kazaları sonucu her yıl sürekli ya da geçici iş göremez raporu alan veya hayatını kaybeden çok sayıda işçi bulunmaktadır. Resmi açıklamalar incelendiğinde, çok az sayıda iş kazası sonucu ölüm verisi görülmektedir. Fakat resmi veriler, belirli iş kazaları raporları ile kıyaslandığında güvenilir sonuçlar vermemektedir. Türkiye'de ise Sosyal Sigortalar Kurumu (SSK) verilerine göre 2003 yılına kadar azalan ölümcül iş kazalarının sayısı 2003 yılından başlayarak artış göstermeye başlamıştır (Akgün vd., 2010, s.623). 
Artan risk ve tehlikelerle beraber temizlik işlerinde iş sağlığ1 ve güvenliğinin önemi artmaktadır. Çalışanların uzmanlarca verilen iş sağlığ1 ve güvenliği eğitimlerini önemsemeleri iş kazalarının önlenmesinde önemli rol oynamaktadır. Çalışanların bu eğitimlere önem vermeleri tehlikeli hareket yapmaktan kaçınmalarını sağlamaktadır. Yapılan risk analizi, denetim raporu gibi işletmede görülen tehlikelerin ve risklerin belirlendiği dökümanlar tehlikeli bir ortam oluşmasını engelleyebilmektedir.

İş kazalarına, yoğun şekilde çöp toplama ve temizlik işleri iş alanlarında rastlanılmaktadır. Bu konuda çeşitli araştırmalar gerçekleştirilmiştir. Örneğin, 1992' de Danimarka'da gerçekleştirilen bir araştırmada, çöp toplama endüstrisinde çalışan işçilerin, bütün işkollarına oranla 5-6 kat daha fazla iş kazası riski altında olduğu belirlenmiştir (Paulsen vd., 1995). Benzer şekilde, Amerika'da 2007 yılında yapılan araştırmaya göre, çöp toplama işlerinde çalışanların ölümcül olmayan iş kazası oranının \%7,5 oranında açıklanmış, diğer işkollarına göre oldukça yüksek olduğu görülmüştür (Akgün vd., 2010, s.628).

Temizlik çalışanları genel olarak, fiziksel, kimyasal, biyolojik, ergonomik ve psikososyal gibi faktörler düşünüldügüüde risk altında bulunmaktadır. Bu çalı̧̧mada, kamu kurumlarında temizlik işlerinde çalışan personellerin karşılaşacağı tehlike ve risklerin tespit edilerek, iş sağlığ ve güvenliği bakış açısından bu etmenlerin karşısında çalışanların ve işverenlerin tutumlarının neler olduğunun ortaya konulması amaçlanmıştır. Çalışmanın kapsamına Alanya Belediyesi bünyesinde temizlik işlerinde çalışan personellerin karşılaşılabilecekleri fiziksel, kimyasal, ergonomik, psikososyal ve mekanik risk etmenlerine karşı yapılan risk değerlendirmesi dahil edilmiştir.

Bu çalışmada, ilerleyen bölümlerde sırasıyla temizlik işlerinde iş sağlığ1 ve güvenliği hakkında yapılan literatür çalışmaları, risk faktörlerinin tanımları, çalışma kapsamında kullanılan yöntem, bulgular, sonuçlar ve öneriler ele alınmıştır.

\section{Literatür}

Temizlik işleri çalışmalarında iş sağlığı ve güvenliği uygulamaları hakkında literatürde yapılmış olan çalışmalar bu bölümde incelenmiştir. 
Aickin (1997) çalışmasında, temizlikçilerin sırt, boyun, omuzlar, dirsekler ve elleri etkileyen kas-iskelet sistemi sorunları geliştirme riskinin yüksek olduğu sonucunu elde etmiştir. Ayrıca, iş esnasında temizlikçiler tarafından elle taşınan ağırlıkların genelleme yapılacak olursa $2 \mathrm{~kg}$ ile 42 $\mathrm{kg}$ arasında değiştiğini belirtmiştir. Temizlikçilerin yürüttüğü görevlerin (örneğin, parlatma makineleri kullanmak, paspaslamak, mobilya taşmak, çöpleri taşımak/boşaltmak) kardiyo solunum ve kas-iskelet sistemi için zorlayıcı faaliyetler olduğu ifade edilmiştir. Diğer çalışma alanlarında söz konusu olan organizasyonel ve psikososyal risk faktörlerinin (iş ve molalar üzerinde kontrol eksikliği, yüksek iş yükü ve zaman baskısı gibi) temizlik işinde de mevcut olduğu kabul edilmiştir. 1998 yılında Aickin ve Carrasco tarafından gerçekleştirilen çalışmada, iş tasarımı, personel seviyeleri, ekipman değiştirme ve bakım programları, iş organizasyonu, eğitim ve kurumlar, temizlikçiler ve temizlik şirketleri arasındaki arayüzü iyileştirerek temizlikçiler için manuel işleme risklerini kontrol etmeye yönelik öneri sistemi kullanılmıştır.

De Vito vd. (2000) temizlik işçilerinin, sosyal statü sınıfının en alt seviyesinde yer aldığını, genellikle düşük gelir ve sosyal destek seviyesi ile düşük eğitimli yaşlı kadınların oranının yüksek olduğunu belirttikleri çalışmalarında, özellikle kas-iskelet bozukluklarının varlığını vurgulamayı amaçlamışlardır. Çalışmada, anamnestik ve klinik verilerin toplanması için standart anketler ve protokoller kullanılmıştır. Sonuçlar, iş organizasyonu ve ergonomik olmayan araçların neden olabileceği dirsek, el bileği/el ve servikal omurga rahatsızlıklarının yaygınlığının arttığını göstermiştir.

Kumar vd. (2005) temizlik sorunlarını belirlemek amacıyla gerçekleştirdikleri çalışmada, katılımcı ergonomi yöntemini uygulayarak düşük maliyetli bir iyileştirmenin bir ofis ortamında temizlikçilerin çalışma duruşları üzerindeki etkisini değerlendirmişlerdir. Bu çalışma ile katılımcı ergonominin ergonomi problemlerini belirlemek ve çözmek için uygun bir ergonomi aracı olduğu sonucuna varılabilmektedir. Düşük maliyetli bir iyileştirme, bir ve iki bükülmüş diz üzerinde oturmak ve bir kolu omuzun üstünde tutmak gibi uygun olmayan davranışları ortadan kaldırarak temizlikçilerin çalışma duruşları iyileştirilmiştir. İyileştirilmiş bir ortamda çalışmanın, daha iyi çalışma duruşlarına yol açabileceği ve 
bunun da temizlikçilerin daha iyi sağlık ve daha iyi temizlik sonuçlarına yol açacağı sonucuna yer verilmiştir.

Woods ve Buckle (2006) çalışmalarında, İngiltere'deki temizlikçilerin kas-iskelet sistemi sağlığı ile ilgili bir araştırma gerçekleştirmişlerdir. Temizlik işi organizasyonu ve uygulamalarına, sağlık ve işyeri sorunlarını azaltmak için amirlerin ve yöneticilerin temizlikçilerle çalışmasına yönelik tavsiyelere odaklanılmıştır. kas-iskelet sistemi hastalıkları için potansiyel risk faktörlerini belirlemek amacıyla anket çalışması gerçekleştirilmiştir. Çalışmanın bulgularına dayanarak, kas-iskelet hastalıklarının azaltılması için temizlik süpervizörleri, yöneticiler, eğitmenler, tasarımcilar ve üreticilerden oluşan gruplara öneriler sunulmuştur.

Güven (2006) çalışmasında temizlik personelinin hizmet içi eğitimlerinin iş hayatında önemli bir yere sahip olduğunu vurgulamıştır. Hizmet içi eğitimin bilgilerini ve becerilerini önemli bir oranda artırdığını, çalıştıkları kurumda meydana gelen değişikliklerden haberdar olup değişiklikleri daha iyi anladıklarını, eğitim almalarının onları eğitimli arkadaşlarının yanında daha eğitimli yaptığını düşünmektedirler. Yapılan araştırmada lise mezunu erkeklerin kadınlardan daha fazla olduğu görülmüştür. Çalışanların büyük kısmı ise erkeklerden oluşmakta ve emeklerinin karşılı̆̆ının alamadıkları için işlerini sevmemektedir.

Akgün vd. (2010) tarafından gerçekleştirilen çalışmada, çöp toplama işçilerinin çöp kamyonu şoförlerine kıyasla daha fazla iş kazası geçirmiş olduğu görülmektedir. Bunun sebebi çöp toplama işçilerinin tekrarlayan hareketler, kırık cam parçaları, termal konfor vb. riskler ile daha fazla karşılaşması ve bu yüzden iş kazası geçirme alanının daha fazla olması şeklinde yorumlanabilmektedir. Temizlik işlerinde çalışan personelin yaptığ1 işten dolayı toplum tarafından gördüğü saygı azdır. Temizlik işleri çalışanları temas ettikleri çöpler sebebiyle sürekli sağlık riskleri ile karşı karşıya kalmaktadır.

Bello vd. (2009), temizlik işleri ile ilgili yaptığı çalışmasında, kimyasallarla ilgili solunum maruziyet potansiyelini nitel olarak değerlendirmiş, sonuç olarak düşük, orta veya yüksek maruziyet tanımlamaları yaparak bir sınıflandırma sunmuştur.

Şahin ve Gürcanlı 2012 yılında yapmış oldukları çalışmada, risk ve tehlikelerin önceden belirlenip gerekli önlemeler alınmasının faydalı olacağı kanısına varmışlardır. Bu çalışmada da kullanılmış olan yöntem- 
lere benzer bir sistem ile risk düzeyleri önemsiz risk, katlanılabilir risk, orta düzey riskler, önemli riskler, katlanılamaz riskler olarak tespit edilmiştir. Önem sırasına göre riskler ivedi bir şekilde düzenlenmelidir vurgusu yapılmıştır.

Akkuş (2013) çalışmasında periyodik kontrollerin önemimden bahsetmiştir. Periyodik kontrolü olan kaldırma araçlarının iş kazasına sebebiyet vermeyeceğine değinmiştir. Ağır ve tehlikeli işlerde çalışacak personelin işe başlamadan önce sağlık muayenelerinden geçirilip işe başlatılması gerektiğini savunmuştur. Sağlık muayenelerinin faydaları olarak personelin hastalıklarının tespit edilip hepatit, tetanos gibi aşıların takibinin kolay olacağı Belirtilmiş, bulaşıcı hastalıklardan kaynaklanan risklerden bahsedilmiş ve önerilerde bulunulmuştur. Araştırma kapsamında iş sağllğ 1 ve güvenliği kültürünün oluşmasının ne kadar önemli olduğu vurgulanmıştır. Bunun yanında ergonomik, biyolojik vb. risklere değinilmiş olup önerilerde bulunulmuştur.

Sarılar (2015) çalışmasında Kinney metodu kullanmıştır. Kinney metodu işletmenin risklerin derecelendirme sonuçlarına göre hangi işlere öncelik verilmesi gerektiğini gösteren bir yöntemdir. Formül olarak "Risk = İhtimal x Frekans x Etki" şeklinde de ifade edilebilmektedir. Sonuç olarak bu çalışmada 80 tane farklı tehlike tespit edilmiş ve bu sonucun oluşmasında çalışanların eğitim eksikliği ve güvenlik kültürünün olmamasının etkili olduğu belirtilmiştir. Yapılan çalışma ile sağlık koşullarının iyileştirilmesi işletmeye katkı sağlamıştır.

Gündoğdu (2016) kamu çalışanları ve özel çalışanları ayrı olarak incelemiştir. İki durum için saha çalışmaları ile karşılaşılabilecek tehlike ve riskler belirlenerek önerilerde bulunulmuştur. Çalışanların karşılaşabileceği fiziksel, kimyasal, biyolojik, ergonomik ve psikososyal risk etmenleri incelenmiş olup buna bağlı iş güvenliği ve sağlığ şikayetleri giderilmeye çalışılmıştır.

Kol (2016) her açıdan toplumu zarara uğratan iş kazaları ile meslek hastalıklarının hem bireylerden hem de işyerlerinin çalışma koşullarından kaynaklanan aksaklıklar sebebiyle meydana geldiğini vurgulamıştır. İş kazası sebeplerini tehlikeli ortam ve tehlikeli hareket şeklinde ikiye ayırmıştır. Tehlikeli ortamın saha denetimleri, risk analizleri gibi yöntemlerle, iş sağlı̆̆ ve güvenliği tedbirlerini almakla giderilebileceğini savunmuştur. Tehlikeli hareketlerin, yani çalışanların tehlikeli davranış- 
larının iş sağlığı ve güvenliği eğitimleri ile güvenlik kültürünün oluşmas1 sonucu giderileceğini düşünmüştür.

Ayan (2017) tarafından gerçekleştirilen araştırma kapsamında ergonomik, kimyasal, fiziksel, psikososyal risk faktörleri incelenmiş olup, çalışanların iş kazasına maruz kalması önlenmeye çalışılmıştır. Yaptıkları işe özgü kişisel koruyucu donanımlar teferruatlı bir şekilde ele alınarak önerilerde bulunulduğu görülmüştür. Kaynak çalışmaları sırasında meydana gelen 1şınlar, patlama riski bulunan bölgeler, elektrik tehlikeleri, tüp tehlikeleri gibi tehlike ve riskler için önlemler alınmıştır.

Güler (2017) çalışmasında, belediyelerde iş sağlığı ve güvenliği sisteminin oluşturulmasının öneminden bahsetmiştir. Belediyelerin genel olarak bir Ortak Sağlık Güvenlik Birimi'ne bağlı iş güvenliği uzmanı ve iş yeri hekimiyle çalıştıkları belirtilmiş, çalışanların periyodik kontrollerinin, eğitimlerinin ve İSG çalışmalarındaki diğer koordinasyonların söz konusu İSG birimi tarafından takip edilmesi gerektiği ifade edilmiştir. Çalışanların periyodik kontrolleri için ise özel tıp merkezlerinden hizmet alımı yapılabileceği savunulmuştur. İSG biriminin yapacağı diğer bir çalışma da acil durum planlarının oluşturulması olup, bu planlarda acil durum ekipleri ile acil durum ekiplerinin eğitimleri ayrıntılı şekilde ele alınmalıdır.

Akman ve Yavuz (2018) araştırmalarında çalışanları taşeron personel, memurlar ve işçiler olmak üzere üç gruba ayırmışlardır. Bu gruplarda yer alan personel için kurum imajı, iş güvencesi, ücret faktörleri arasındaki farklılıklar incelenmiştir. Yapılan analiz sonucunda kurumun imajından en memnun olanların işçiler olduğu görülmüştür. En az memnun olanlar ise taşeron işçiler olup, taşeron işçilerin bu yüzden kurumlarını değiştirmekte sakınca görmedikleri ifade edilebilmektedir.

Ayna (2018) çalışmasında 3T risk değerlendirme yöntemi kullanmış olup, bu yöntem uygulama açısından kolaylık sağlayan bir değerlendirme yöntemidir. Her bölümün tek tek incelendiği sistemde, belirlenen tehlike ve riskler tekrar kontrol aşamasında diğer değerlendirme yöntemlerine göre kolaylıklar sağladığı vurgulanmıştır.

Özcan ve Kızıl 2020 yılında gerçekleştirdikleri çalışmada; aşçı, temizlik personeli ve idari personel üzerinden tespitler yapmaya çalışmışlardır. Yetersiz beslenenlerin oranı temizlik işleri çalışanlarında daha yüksek görülmüştür. Bu üç grup incelendiğinde en düşük ücreti temizlik 
işleri çalışanlarının aldığı görülmüş, bu yüzden çalışma yıllarının daha düşük olduğu vurgulanmıştır. İş stres düzeyi de temizlik işlerinde daha yüksek görülmüştür. Bunun için ise diğer personellerden daha fazla mesai yapılması ve saygınlığının daha az olması sebep olarak gösterilebilmektedir.

Özer (2018) araştırmasında Domino Teorisine değinmiştir. Bu teoride anlatılmaya çalışılan domino oyununda olduğu gibi, başta yapılan hata yüzünden tüm taşların devrilmesidir. Bu teori "iş sağlığı ve güvenliği çerçevesinde alınacak önlemler en başta alınmalıdır ki iş kazası ve ramak kala olay yaşanmasın" şeklinde görüşü ifade etmektedir. Teoriye göre çalışma ortamındaki iş kazalarının \%88'ini tehlikeli hareketlerden yani çalışanların yapmış olduğu davranışlardan, \%10'luk kısım ise tehlikeli durumlardan yani çalışılan işyerindeki eksikliklerden kaynaklanmaktadır. Buradan çıkan sonuç iş kazalarının \%98'inin önlenebilir durumda olduğudur. Kazaları önlemek için eğitim, saha gözetimi, sağlık gözetimi gibi iş sağlığı ve güvenliği önlemleri alınarak daha sağlıklı ve güvenli bir ortam oluşturabilmektedir. Yapılan çalışma, çalışan personelin yapmış olduğu davranışlar sonucunda iş kaza oranının artmakta olduğunu göstermektedir. İş kazalarını önlemek için personelin iş sağlığ1 ve güvenliğine verdiği önemin artması gerektiği vurgulanmaktadır.

Ünsal (2019), çalışma ortamında karşılaşılabilecek tehlike ve riskleri tespit ederek önerilerde bulunmuştur. Çalışma ortamları belirli aralıklarla kontrol edilerek alınan önlem ve tedbirlerin ne kadar uygulandığ 1 ve uygulanan kısımların ne derece düzeldiği takip edilmiştir. Çalışan personelin kullanmaları gereken kişisel koruyucu donanımlar tespit edilmiş ve kullanımları anlatılmıştır. Değişik metotlar kullanılarak olaylar göz önüne serilmiştir.

\section{Tanımlar ve Risk Faktörleri}

Yönetim ve Bütçe Ofisi tarafından 2006 yılında risk değerlendirmesi, "potansiyel bir tehlikenin mevcut olup olmadığını ve/veya insan sağlığı, güvenliği veya çevreye yönelik olası riskin kapsamını belirlemek için bilimsel bilgileri bir araya getiren ve sentezleyen bilimsel ve/veya teknik bir belge" şeklinde tanımlanmıştır (National Research Council, 2007). 
Temizlik işlerinde risk değerlendirmesi yapabilmek amacıyla ilk olarak ortaya çıkan ya da çıkabilecek risklerden bahsedilmesi, kısaca tanımlanmaları gerekmektedir. Bu sebeple bu bölümde çalışmaya dayanak oluşturan temizlik işlerinde genel olarak karşılaşılan ana risk faktörleri açıklanmıştır.

\section{Fiziksel Faktörler}

Aydınlatma: Aydınlatmanın istenen düzeyde olmaması güvensiz bir ortamın oluşmasına yol açabilmektedir. Güvensiz bir ortam oluşması ise iş kazası, ramak kala olay gibi istenmeyen olaylara sebep olabilmekte ve özellikle temizlik işlerinde ofis, depo gibi alanlarda iş kazasına sebebiyet verebilmektedir. Temizlik işlerinde önem taşıyan bir diğer konu ise acil durum aydınlatmasıdır, aniden kesilen elektriğin iş kazasına sebep vermemesi için kaynağı başka bir yerden beslemeli acil durum aydınlatması temin edilmesi gereklidir. Acil durum aydınlatmasının yönetmelikte geçen kısımları şu şekildedir;

“Bütün kaçış yollarında, toplanma için kullanılan yerlerde, asansörde ve yürüyen merdivenlerde, yüksek risk oluşturan hareketli makineler ve kimyevi maddeler bulunan atölye ve laboratuvarlarda, elektrik dağıtım ve jeneratör odalarında, merkezi batarya ünitesi odalarında, pompa istasyonlarında, kapalı otoparklarda, ilk yardım ve emniyet ekipmanının bulunduğu yerlerde, yangın uyarı butonlarının ve yangın dolaplarının bulunduğu bölümler ile benzeri bölümlerde acil durum aydınlatması şarttır... Acil durum aydınlatmasının normal aydınlatmanın kesilmesi hâlinde en az 60 dakika süreyle sağlanması şarttır. Acil durum çalışma süresinin kullanıcı yükü 200'den fazla olduğu takdirde en az 120 dakika olması gerekir."

Aydınlatmanın yeterli olduğu bir çalışma alanında çalışanların iş kazası geçirme riski azalabilmekte. ve çalışanların iş verimleri daha üst seviyelere çıkabilmektedir. Temizlik işlerinde incelemelerde bulunulan çalışma alanlarında aydınlatmanın yeterli seviyede olduğu görülmüştür.

Termal Konfor: Termal konfor, ortamda bulunan kişilerin aktivitelerine devam ederken sıcaklık, nem ve hava akım hızı gibi ortam şartları bakımından belirli rahatlık içerisinde bulunup bulunmadıklarını ifade et- 
mektedir. Ortamın termal konfor şartları yetersiz ise çalışanların veriminin düşmesine ve iş kazası, ramak kala olaya sebep olmaktadır. Temizlik işleri göz önünde bulundurulduğunda; ofis ortamında çalışan personel için doğal havalandırma uygundur. Doğal havalandırmanın yetersiz olduğu durumlarda ise klima vb. kullanılması gereklidir. Çalışma alanı dışarıda ve açık havada olan (süpürge, araç arkası gibi) personel için çalışma ortamının termal konfor şartlarına uygun hale getirilmesi, ortam ölçümlerinin yapılması, getirilemiyorsa personellerin belirli aralıklarla dinlendirilmesi ve sağllk gözetimlerinin sürekli hale getirilmesi gereklidir. Soğuk havalarda çalışan personel için ise uygun giysi kullanımında iş kazasına sebep verecek ortamlar ortadan kaldırılmış olacaktır, ayrıca ara dinlenmeleri arttırılarak personel dinlendirilmelidir.

Kimyasal Faktörler: Temizlik işlerinde yapılan işlerden dolayı çalışanlarda zararlı etkiler meydana getiren gazlar açı̆̆a çıkmaktadır. En yaygın kimyasal riskler, bu maddelerin ciltle veya gözle temas etmesi, solunması veya yutulmasıdır. Özellikle kapalı ortamlar kimyasallar için daha yüksek bir tehlike unsurudur. Tankerler, kazanlar, basınçlı kaplar, derin çukur ve oyuk benzeri açık boşluklar, kanalizasyon tesisleri, kuyular, kanallar ve benzeri yapılar, faydasız ve terk edilmiş boşluklar temizlik işleri için bir tehlikedir. Genellikle açığa çıan gazlar metan ve hidrojen sülfürdür. Metan gazı renksiz, kokusuz, patlayıcı ve zehirli olmayan bir gazdır. Boğucu özelliği oksijen oranını \%12 altına düşürünce ortaya çımaktadır. Metan gazı temizlik işlerinde kanalizasyon ve çöplerin olduğu alanlarda görülmektedir. Sık rastlanan diğer gaz ise hidrojen sülfürdür. $\mathrm{Bu}$ gaz ise renksiz, çürük yumurta kokusunda, zehirleyici olup, kanalizasyonda birikmekte ve havadan ağırdır. Temizlik işlerinde çalışanların bu gazlardan korunmasının sağlamak için yaptıkları işe özgü eğitimlerinin olması gereklidir. Tehlikeli bir ortamla karşılaştıklarında ne gibi tedbir almalarını bilmeleri sayesinde iş kazası ve ramak kala olayın meydana gelmesi önlenmiş olmaktadır. Kanalizasyon sisteminde biriken gazların işe başlamadan önce ölçümünün yapılması tehlikeli bir ortam olup olmadığının anlaşılmasını sağlayacaktır. Daha sonra ise çalışma yapmadan önce filtreli maskelerin ve uygun iş kıyafetlerinin giyilerek işe başlanması gerekmektedir. 
Temizlik işlerinde tehlikeli bir ortam oluşturacak diğer bir durum ise boya işleridir. Boya işleri genellikle deri ile temas halindedir. Boya ile bazı maddelerin karışması sonucu solunum yolu içinde tehlike oluşturmaktadır. Boya bidonlarının sızdırmaz şekilde bulundurulması gereklidir. Çalışanların uygun eldiven ve solunum koruyucu maskeler kullanması tehlikeli ortamdan korunmalarını sağlamaktadır. Ayrıca boya işleri çalışanları için yakın mesafesinde temiz su akan lavabolar olması göze ya da yüze sıçrayan maddeleri hemen temizlemek için bir avantaj sunabilmektedir.

Araç yıkama ve çalışma alanını temizleyen personelin, temizlik yaparken kullandığı malzemeleri iyi tanıması gereklidir. Bazı temizlik malzemeleri cilt ve göz yanıklarına sebep olabilmektedir. Temizlik malzemeleri depolanırken, birbiri ile temasa girdiğinde tehlikeli bir ortam oluşturacak malzemelerin ayrı yerde depolanması gerekmektedir. Bazı kimyasallar tek başına tehlikeli değilken tepkimelerinden meydana gelecek gaz çalışanlar için tehlikeli olabilmektedir. Kimyasal depolama alanlarına uygun yangın söndürücü bulundurulması çalışanların ve dişarıdan gelebilecek olan ziyaretçilerin korunması açısından büyük önem taşımaktadir.

Kimyasalların yanlış kullanımını önlemek için Güvenlik Bilgi Formları çalışanların anlayacağı şekilde asılmalıdır. Ayrıca kullanılacak kişisel koruyucu donanımların resimleri de bulundurulmalıdır. Kimyasallar asla etiketsiz bir kutu içinde kullanılmamalıdır. Çoğu çalışma alanında kimyasallar su şişeleri içinde taşınmaktadır, su şişelerinde taşınan kimyasallar ayrıca dışarıda halkın aktif şekilde bulunduğu alanlarda çok tehlikeli bir ortam oluşturmaktadır.

Ergonomik Faktörler: Temizlik işlerinde, işlerin büyük bir kısmı fiziksel güç gerektirmektedir. Uzun süreli ayakta çalışma için, süpürge personeli, moloz ve budama atığı toplama personeli örnek gösterilebilir. Dinlenme süreleri arttırılarak iyileştirmeler yapılabilmektedir. Ayakta uzun süre çalışmak varis problemlerini ortaya çıkarabilmekte, bunun için de uzun süreli ayakta çalışmalarda ayak egzersizleri yapılabilir. Elle taşıma ve kaldırma tehlikesine genellikle depo personeli ve ofis personelleri maruz kalmaktadır. Taşınacak yükün seviyesine inip almak sırt incinmelerini azaltabilir. Diğer bir tehlike ise çalışma alanının dar olmasıdır. 
Çalışma alanının dar olması yükü kavramak açısından zorluk oluşturmakta ve sırt incinme riskini arttırmaktadır. Elle taşıma ve kaldırma işlerinde eldiven kullanmak iş kazalarını önleme imkanına sahiptir.

Ergonomik faktörler için tekrarlanan hareketlere araç arkası ve süpürge personeli ile şoförler örnek verilebilir. Tekrarlanan hareketler kas rahatsızlıklarına sebep olabilmektedir. Dinlenme araları arttırılarak ve esneme hareketleri yapılarak olumsuz durumun ortadan kaldırılması sağlanabilmektedir.

Ofis çalışanları sürekli oturur pozisyonda çalışmaktadır. Bu durum kas iskelet sistemi için zarar oluşturabilmektedir. Belirli sürelerde esneme hareketleri yapılması, sandalyelerinin ergonomik olması tehlikeli ortamın oluşmasını önleyici unsurlardır. Çalışma ortamında kullanılan bilgisayar konumlarının uygun olması gerekmekte, bilgisayar ve çalışan arasında uygun mesafe olması hem göz sağlığının korunması hem de duruş bozukluğunun giderilmesi için önemlidir. Bilgisayar ile çalışan bir personelin göz kuruluğu yaşama olasılığı yüksektir. Bunun için gözler belirli sürelerde dinlendirilmelidir.

Mekanik Faktörler: Temizlik işlerinde; çeşitli makine ve araçlar kullanılmaktadır. Hareketli/döner aksamlı makine kullanımında yırtık, püsküllü makineye takılabilecek kıyafetler kullanılmamalıdır, ayrıca kolye gibi takılar takılmamalıdır. Çöp kamyonu işçileri özellikle bu duruma maruz kalabilmektedir. Ayrıca makinelerin enerjileri kesilmeden bakım ve temizliğinin yapılması (örn: elektrik panosunun bakımı yapılırken enerjisinin kesilmesi), bakım temizlik sonrası koruyucuların yerlerine takılmaması (örn: elektrikli testerenin koruyucusunun olmaması) başlıca iş kazası sebeplerindendir.

Psikososyal Faktörler: Temizlik işlerinde uzun çalışma süreleri olması, ara dinlenmelerin ihlali, haftalık tatil kullandırılmaması, iş üzerindeki kontrol yetersizliği, yarı vasıflı-vasıfsız çalışma, iş hızı ve zaman darlığı, rol belirsizliği gibi konular psikososyal risklerin en temel sebepleri arasındadır. İşin yapısı gereği çalışma saatlerinin esnekliği, akşam ve gece çalışmalarının fazlalığı, tekrarlayıcı ve tekdüze iş, iş-aile yaşamının dengesizliği, fazla iş yükü, personel veya konuklar tarafından şiddet ve baskı görülmesi sektördeki psikososyal risklerin diğer kaynakları arasında 
gösterilebilmektedir. Psikososyal risk faktörleri çalışanların işe karşı bağlılığını, verimliliğini ve iş tatminlerini olumsuz etkilemekle birlikte iş kazasına sebebiyet verebilmektedir.

\section{Yöntem}

Çalışma kapsamında ofis, saha, çalışma alanları ve depolar çalışan personel yardımıyla denetlenerek incelemelerde bulunulmuştur. Çalışma alanlarındaki oluşan tehlikeleri belirlemek, işletmedeki mevcut durumun ne olduğunu görmek, zarardan kimler etkilenebileceğini tespit etmek amaçlanmıştır.

Çalışan personel ile yüz yüze görüşülüp yaptıkları iş ile ilgili çalışmaları yerinde incelenmiş, çalışma alanındaki tespit edilen tehlikeli davranış ve tehlikeli durumlar fiziksel, kimyasal, ergonomik, mekanik, psikososyal faktörler göz önüne alınarak değerlendirilmiştir. Kişisel koruyucu donanımların yaptıkları işe özgü olup olmadığı kontrol edilmiştir.

Bu çalışma ülkemizde bulunan yerel yönetimlerce işletilen temizlik işlerinde çalışanların çalışma ortamlarını ve sağlık koşullarını iyileştirmek amacı taşımaktadır. Çalışma kapsamında temizlik işlerinde risk yönetimi için ilk önce risk değerlendirme uygulaması gerçekleştirilmiştir. Değerlendirme, saha, ofis, dinlenme alanı, yemekhane gibi alanlardaki faaliyetleri kapsamaktadır. Risk değerlendirmesi dört aşamadan oluşmakta olup her bir aşama alt başlıklar halinde sunulmuştur.

\section{Tehlikelerin Tanımlanması}

Tehlikeler tanımlanırken çalışma ortamı, çalışanlar ve işyerine ilişkin ilgisine göre asgari şekilde belirtilen bilgiler toplanmaktadır. İşyeri bina ve eklentileri, iş ekipmanları, kullanılan kimyasal maddeler, makinelerin ve basınçlı kapların periyodik kontrolleri ve ortam ölçümleri, acil durum planları, özel politika gerektiren çalışanlar gibi başlıklarda olası tehlike kaynakları belirlenmektedir.

İhtimalin Hesaplanması: Tespit edilmiş olan tehlike veya tehlike kaynaklarının her birisi ayrı ayrı dikkate alınarak bu tehlikelerden kaynaklanabilecek risklerin hangi ihtimalde oluşacağı ile bu risklerden kimlerin, 
nelerin, ne şekilde ve hangi şiddette zarar görebileceği belirlenmektedir. Bu belirleme yapılırken mevcut kontrol tedbirlerinin etkisi de göz önünde bulundurulmaktadır. Gerçekleşme ihtimali değerlendirilirken Tablo 1'den faydalanılmaktadır.

Tablo 1. Bir Olayın Gerçekleşme İhtimali

\begin{tabular}{lcl}
\hline İhtimal & $\begin{array}{c}\text { Sayısal } \\
\text { Değeri }\end{array}$ & $\begin{array}{l}\text { Ortaya Çıkma Olasılığı İçin Derecelendirme Basamak- } \\
\text { ları }\end{array}$ \\
\hline Çok küçük & 1 & Hemen hemen hiç \\
Küçük & 2 & Çok az (Yılda bir kez ), sadece anormal durumlarda, \\
Orta & 3 & Az ( Yılda bir kaç kez ) \\
Yüksek & 4 & Sıklıkla ( Ayda bir ) \\
Çok yüksek & 5 & $\begin{array}{l}\text { Çok sıklıkla ( haftada bir, her gün ), normal çalışma } \\
\text { şartlarında }\end{array}$ \\
\hline
\end{tabular}

\section{Şiddetin Hesaplanması}

Gerçekleşme ihtimali olan bir olayın gerçekleşmesi durumunda etkisinin belirlenmesidir. Olayın şiddeti olarak ifade edilir ve derecesi Tablo 2'de yer alan ölçütlere göre değerlendirilmektedir.

Tablo 2. Bir Olayın Gerçekleştiği Takdirde Şiddeti

\begin{tabular}{lcl}
\hline Sonuç & Sayısal Değeri & Derecelendirme \\
\hline Çok hafif & 1 & $\begin{array}{l}\text { İş saati kaybı yok, hemen giderilebilen, ilk yardım } \\
\text { gerektiren }\end{array}$ \\
Hafif & 2 & $\begin{array}{l}\text { İş günü kaybı yok, kalıcı etkisi olmayan ayakta tedavi } \\
\text { Orta }\end{array}$ \\
Ciddi & 3 & Hafif yaralanma, yatarak tedavi/yaralanma \\
Çok ciddi & 5 & Ciddi yaralanma, uzun süreli tedavi, meslek hastalığ \\
\hline
\end{tabular}

\section{Risk Değerinin Hesaplanması}

Bir tehlikenin ihtimali ve şiddeti göz önüne alınarak risk skorunun belirlenmesidir. Tablo 1 ve 2' deki sayısal değerler kullanılarak her bir tehlike için Denklem 1'de sunulan formülle hesaplanmaktadır.

Risk Skoru $=($ Tehlikenin Gerçekleşme İhtimali $) \times($ Tehlikenin Şiddeti $)$ (Denklem 1)

Elde edilen değerler sonucunda risk skoru 1-6 arasında olan tehlikeler düşük (kabul edilebilir), 8-12 arası olanlar orta (dikkate değer), ve 15-25 
arasında olanlar da kabul edilemez risk olarak sinıflandirılmaktadır. Ortaya çıkan risk değerine göre Tablo 3'te belirtilen faaliyetlerin uygulanması göz önüne alınmaktadır.

Tablo 3. Sonucun Kabul Edilebilirlik Değerleri (Ceylan ve Başar, 2020:12)

\begin{tabular}{|c|c|}
\hline Risk Seviyesi & Faaliyetler / Önlemler \\
\hline $\begin{array}{l}\text { Kabul Edilebilir Risk } \\
1,2,3,4,5,6\end{array}$ & $\begin{array}{l}\text { - Önlem almaya ve kayıt tutmaya gerek yok. } \\
\text { - Ek kontrol gerekmiyor. } \\
\text { - Dikkat ek bir maliyet yükü getirmeyecek daha etkin çözüm- } \\
\text { lere veya iyileştirmelere verilmeli. } \\
\text { - Mevcut kontrollerin uygulanıp uygulanmadığının takibi gere- } \\
\text { kir. }\end{array}$ \\
\hline $\begin{array}{l}\text { Dikkate Değer Risk } \\
8,9,10,12\end{array}$ & $\begin{array}{l}\text { - Riski azaltmak için çaba sarf edilmeli. İncelemenin maliyeti } \\
\text { dikkatle ölçülmeli ve sınıflandırılmalı. } \\
\text { - Risk azaltma önlemleri belirlenmiş zaman periyotlarında } \\
\text { uygulanmalıdır. } \\
\text { - Ciddiyet derecesinin yüksek olduğu, orta dereceli risklerin } \\
\text { bulunduğu yerler için daha ileri değerlendirmeler gerekli } \\
\text { olabilir. }\end{array}$ \\
\hline $\begin{array}{l}\text { Kabul Edilemez Risk } \\
15,16,20,25\end{array}$ & $\begin{array}{l}\text { - Risk azaltılmadan çalışmaya başlanılmaz. } \\
\text { - Risk kaynakları daha az riskli yöntemlerle değiştirilmelidir. } \\
\text { - Bu riskle işin acil devam etmesi halinde acil önlem paketleri } \\
\text { devreye sokulmalıdır. } \\
\text { - Risk tolere edilebilir düzeye getirilene kadar işe başlanmaz. } \\
\text { - Sinırsız kaynaklar kullanılmasına rağmen riski azaltmak } \\
\text { mümkün olmuyorsa iş yasaklanmalıdır. }\end{array}$ \\
\hline
\end{tabular}

\section{Tipi Matris Yöntemiyle Risk Değerlendirmesi}

L tipi matris ( $5 \times 5$ matris diyagramı) sebep-sonuç ilişkilerinin analizinde yaygınca kullanılmakta olan bir yöntemdir (Özkılıç, 2005). Yöntem ayrıntısız bir şekilde uygulanabilen bir yöntemdir. Yalnızca risk değerlendirmesi yapılması gereken iş güvenliği konularında uzmanlar tarafından kullanılmaktadır. Yöntemin başarı seviyesi uygulayıcının L tipi matris yöntemiyle ilgili bilgi ve birikimine göre farklılıklar gösterebilmektedir. Uygulama alanlarını önceliklendirmek gerekirse, L tipi matris yöntemi, işletmelerde aciliyet durumu olan, hızlı bir şekilde önlem alınması gerekli olan tehlikelerin belirlenmesinde uygulanmalıdır (Yavuzkan vd., 2018, s.608). Literatür incelendiğinde, L tipi matris yönteminin farklı alanlarda risk değerlendirmesi konularında uygulandığı da 
görülmektedir. Örneğin; Soykan, 2018 yılında çalışmasında endüstriyel balıkçı gemilerinde L tipi matris yöntemini uygulamıştır. Koltan vd. (2015) çalışanların sağlık uygunluğunun değerlendirilmesinde, Çeliktaş ve Ünlü ise, 2018 yılında bilişim sistemleri alanında L Tipi Matris yöntemini uygulayarak risk değerlendirmesinde bulunmuşlardır.

Çalışma kapsamındaki risk değerlendirmelerinde L Tipi Matris yöntemi kullanılmıştır. Bu yöntemle oluşturulan değerlendirme tablosunda öncelikli olarak uygulamanın yapıldığı ana ve alt faaliyet alanları yer almaktadır. Faaliyet alanlarındaki tehlike kaynağı belirtildikten sonra tehlikeli durum ve davranışı belirtilmektedir. İşletmedeki herhangi bir güvenlik tedbiri alınmadan önce mevcut durum tespit edildikten sonra bu durumdan etkilenecek kişi ve kişiler eklenmektedir. Mevcut durumdan kaynaklanan olasılık ve şiddet çarpılarak ilk risk skoru bulunmaktadır. Daha sonra düzeltici ve önleyici faaliyetler önerilmekte ve öneri sonrası olasılık ve şiddet öngörülerine göre yeni risk skoru belirlenerek tehlikenin ortadan kalkıp kalmadığı sonucuna varılmaktadır.

Çalışma kapsamında 94 risk faktörü değerlendirilmiş olup, örnek olması açısından ilk 7 değerlendirme Tablo 4 'te verilmiştir.

\section{Bulgular}

İşletme çalışanlarının bir tehlike ile karşılaşabilecekleri tüm alanlar faaliyet bölümlerine göre ayrı ayrı ele alınmıştır. Faaliyet alanlarına ayırmak, tehlikeli durum ve davranışları tespit etmekte kolaylaştırıcı olmuştur. Buna göre risk değerlendirmesinin yapıldığı ana faaliyet alanları İşletme Geneli, Eğitim, Saha Çalışmaları, Ofis ve Çöp Toplama Kamyonu olmak üzere beşe ayrılmıştır. $\mathrm{Bu}$ ana faaliyet alanlarının altında bulunan 27 adet alt faaliyet alanları için toplamda 94 adet olası tehlikenin riski, L tipi matris yöntemiyle değerlendirilmiştir. Değerlendirme sonuçları Tablo 5'te özetlenmiştir. Bu tabloda yer alan alt faaliyet alanlarından eğitim, ergonomi, ofis ve çöp toplama kamyonu dışındaki tüm alt faaliyet alanları İşletme Geneli ana faaliyet alanında yer almaktadır. 
Tablo 4. L Tipi Matris Risk Değerlendirme Örneği

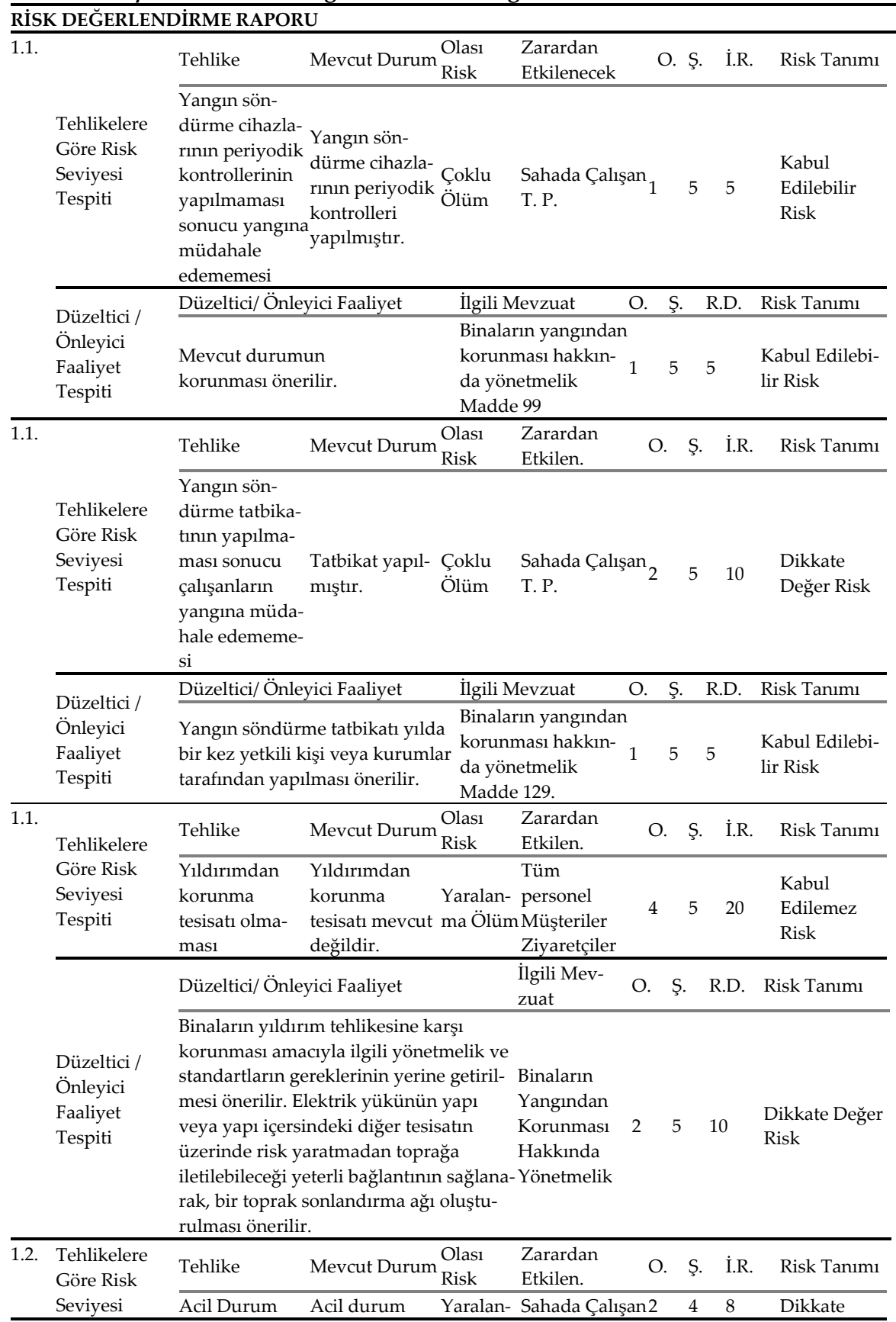




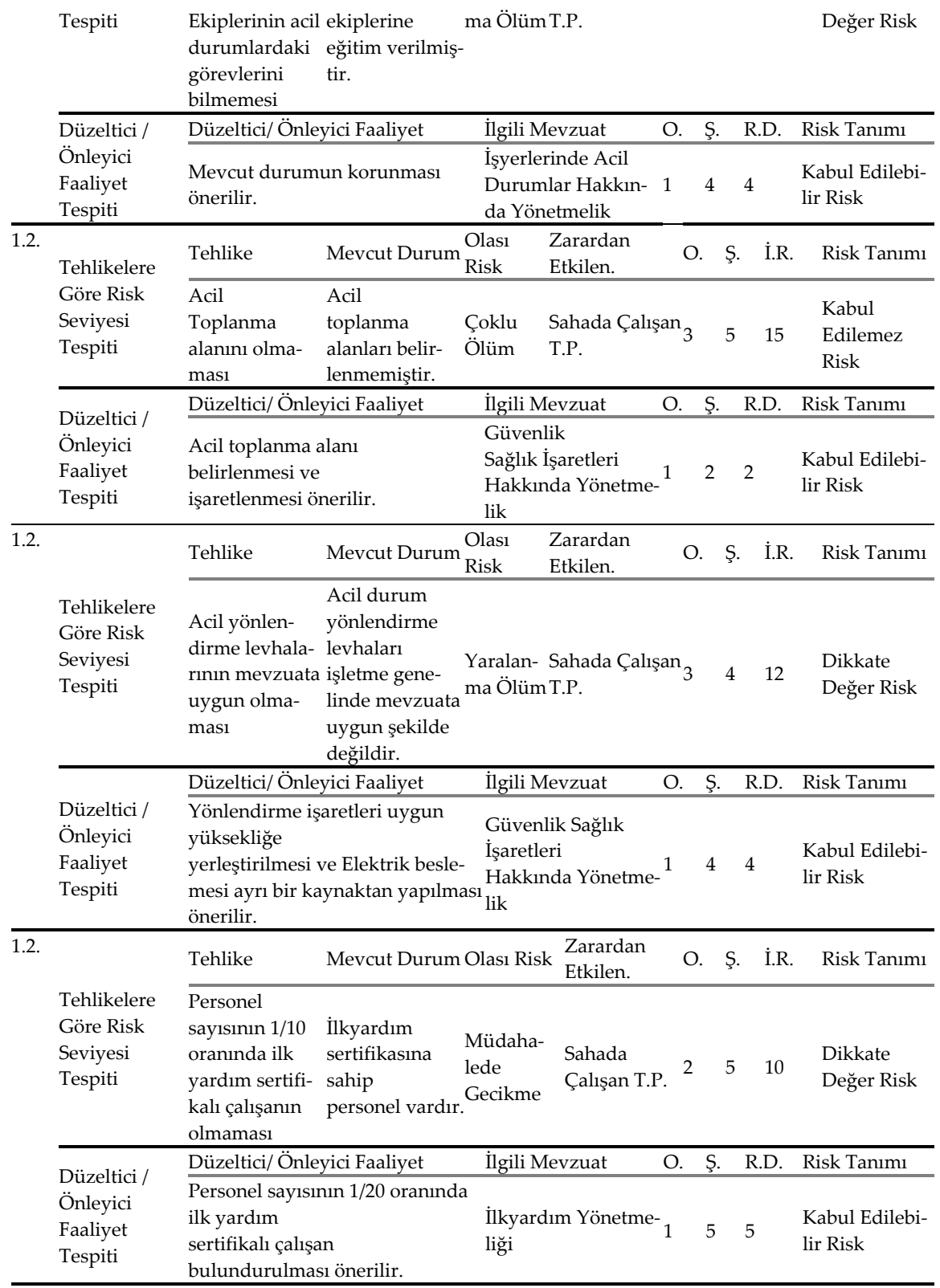

Yangın alt faaliyet alanı 1.1 ile, Acil Durumlar 1.2 ile gösterilmiştir. O.: Olasılık, Ş.: Şiddet, I.R.: Ilk Risk, R.D.: Risk Değeri. 
Tablo 5'te İşletmede tespit edilen 94 riskin alt faaliyet alanına ve risk seviyesine göre dağılımı yer almaktadır. İşletmede 25 adet Kabul Edilemez Risk, 58 adet Dikkate Değer Risk, 11 adet Kabul Edilebilir Risk tespit edilmiştir. Özellikle çalışma alanı, boyama işleri, Kaynak makinesi, Elektrikli el aletleri, çöp kamyonu faaliyet alanlarında yetersiz önlemler olduğundan risk derecelendirmeleri yüksek çıkmıştır.

Tablo 5. Faaliyet Alanlarına ve Öncelik Sıralarına Göre Risk Değerleri Dağılımı

\begin{tabular}{|c|c|c|c|c|c|}
\hline \multirow{2}{*}{ Sira } & \multirow{2}{*}{ Alt Faaliyet Alanı } & \multirow{2}{*}{$\begin{array}{l}\text { Kabul Edilebilir } \\
\text { Risk }\end{array}$} & \multicolumn{2}{|c|}{ Dikkate Değer Kabul Edilemez } & \multirow{2}{*}{ Toplam } \\
\hline & & & Risk & Risk & \\
\hline 1 & Yangin & 1 & 1 & 1 & 3 \\
\hline 2 & Acil Durumlar & & 3 & 1 & 4 \\
\hline 3 & Eğitim & 2 & & & 2 \\
\hline 4 & Sağlık & 2 & 1 & & 3 \\
\hline 5 & Elektrik & & 1 & 2 & 3 \\
\hline 6 & Psikososyal & & 1 & & 1 \\
\hline 7 & Çocuk ve Genç İşçiler & & 1 & & 1 \\
\hline 8 & Güvenlik Sağlık İşaretleri & & 1 & & 1 \\
\hline 9 & Çalışma Alanı & 1 & 8 & 2 & 11 \\
\hline 10 & Ergonomi & & 2 & & 2 \\
\hline 11 & Boyama İşleri & 2 & 6 & 1 & 9 \\
\hline 12 & İstifleme & & & 1 & 1 \\
\hline 13 & Fiziksel Risk Etmenleri & & 2 & 1 & 3 \\
\hline 14 & Elektrikli El Aletleri & & 5 & 2 & 7 \\
\hline 15 & Kaynak Makinesi & & 1 & 6 & 7 \\
\hline 16 & Yüksekte Çalışma & & 2 & 1 & 3 \\
\hline 17 & Tüpler & & 2 & & 2 \\
\hline 18 & Hidrofor & & & 2 & 2 \\
\hline 19 & Kompresör & & & 2 & 2 \\
\hline 20 & Dinlenme Alanı & 1 & 1 & & 2 \\
\hline 21 & Jeneratör & & 1 & & 1 \\
\hline 22 & Ofis & 1 & 3 & & 4 \\
\hline 23 & Depo & 1 & & 1 & 2 \\
\hline 24 & Çöp toplama Kamyonu & & 12 & & 12 \\
\hline 25 & Yol & & 2 & & 2 \\
\hline 26 & Biyolojik Risk Etmenleri & & 2 & & 2 \\
\hline 27 & İş Makineleri & & & 2 & 2 \\
\hline \multicolumn{2}{|c|}{ Toplam } & 11 & 58 & 25 & 94 \\
\hline
\end{tabular}

\section{Tartışma ve Sonuç}

Temizlik işlerinde iş sağlığı ve güvenliğinin temini için yapılan çalışma neticesinde elde edilen sonuçlar ve öneriler şu şekildedir:

Çalışanların eğitim seviyesinin düşük olması başlıca bir risk oluşturmaktadır. Yapılan bilgilendirmelerin kavranmasında zorluk çektikleri görülmüştür. Bu yüzden iş sağlı̆̆1 ve güvenliği eğitimlerine önem 
vermedikleri, alınan iş sağlığı ve güvenliği tedbirlerine uymadıkları, kendilerine sağlanan kişisel koruyucu donanımları bazen kullanmadıkları görülmüştür. Eğitim seviyesi yüksek olan çalışanların bu konularda daha dikkatli oldukları görülmüştür.

Temizlik işlerinde çalışan personelin çöp toplarken kesici, delici aletlerle karşılaştığı görülmüştür. Personel işe uygun eldiven kullanmaktadır. İşyeri Hekimi tarafından tetanos tehlikesi olan işlerde aşılarının yaptırılması konusunda bilgilendirildiği görülmüştür.

Süpürge personeli gibi tekrarlayan hareket yapan personeller belirli aralarla dinlendirildikleri görülmüştür. Esneme hareketleri yapmaları önerilmiştir.

Termal Konfor Faktörlerinin tanım kısmında değinilen çalışma alanı dışarıda ve açık havada gerçekleştirilen temizlik faaliyetlerinde çevreden toplanan su şişelerinde çeşitli kimyasallar olduğu tespit edilmiştir. Bu durumun temizlik personeli için tehlike oluşturması sebebiyle gerekli görülen yerlerde personelin koruyucu kullanmalarına yönelik olarak bölüm amirlerince sözlü şekilde uyarılmaları önerilmiştir.

Yangın ve güvenlik konusunda işletmede gereken önlemler alınmış olmasına rağmen personellerin davranışsal eksiklikleri olduğu tespit edilmiştir. Bölüm amirlerince sözlü şekilde uyarılar yapıldığı, bu uyarıların personel açısından faydalı olduğu görülmüştür.

Şoförlerin kullandıkları araçların kontrolünü düzenli bir şekilde takip ettikleri görülmüştür. Sahada çalışırken sözlü olarak öfke kontrol bilgilendirmesi yapılmıştır.

Kanal açma ve temizleme işlerinde çalışan personel sahada çalışırken gözlemlenmiş olup, çıkabilecek metan ve hidrojen sülfür vb. gazlarına karşı filtreli maskelerin nasıl kullanılacağına dair bilgilendirmesi yapılmıştır. Çalışma yaparken halkın ve çalışanların tehlikeli bir şekilde söz konusu kanal açıklıklarına düşmemesi için önlemler alınmıştır.

Ofis personellerinin ekranlı araç kullanımını iş sağlığı ve güvenliğine uygun yapmadıkları görülmüştür. Çalışma alanlarında doğru oturuş, esneme hareketleri, gözleri belirli sürelerde dinlendirmeleri konusunda bilgilendirilmiştir.

Tüm çalışma alanlarında kullanılan kimyasalların özelliklerinin yazılı olduğu talimatların eksik olduğu görülmüştür. Çalışma alanlarında 
yaptıkları işe uygun kişisel koruyucu donanımların hazır bir şekilde bulunması gerektiği konusunda personel bilgilendirilmiştir.

Acil toplanma alanlarında kısmi eksiklikler görülmüş olup acil toplanma alanlarının tekrar belirlenip personel ile tatbikat yapılması önerilmiştir. Acil durum ekipleri için seçilen personel kontrol edilip bilgilendirme yapılmıştır.

$\mathrm{Bu}$ çalışmada yerel yönetimlerce işletilen temizlik işleri için risk değerlendirmesi yapılmıştır. Çalışma kapsamında değerlendirilen toplam 94 tehlike kabul edilebilir, dikkate değer ve kabul edilemez olarak sinıflandırılmış olup alınması gereken önlem ve öneriler sunulmuştur. İşyerinin taşınması veya işyerinde kısmi değişiklik yapılması, kullanılan makinelerin değişmesi veya makinelere yeni parça takılması, iş kazası veya meslek hastalığı gibi olayların işletmede meydana gelmesi, yapılan ortam ölçümleri ve periyodik kontroller sonucunda yeni tehlikelerin belirlenmesi, yeni tehlikelerin işyerinin tamamını veya bir bölümünü etkilemesi durumlarında risk değerlendirmeleri tamamen veya kısmen yenilenebilir. 


\title{
EXTENDED ABSTRACT
}

\section{Risk Assessment in Cleaning Works: The Example of Alanya Municipality}

\author{
Adem Demir- Mehmet Gümüş- Hacer Yumurtacı Aydoğmuş - Eren Kamber \\ Municipality of Alanya-Alaattin Keykubat University-Alaattin Keykubat University - Alaattin Keykubat University
}

Municipalities have expanded their service areas with the increase of the population and their awareness. The importance and value given to occupational health and safety has increased with the increase in working areas and the use of a new set of machines. Among these working areas, Cleaning Services Works and their working areas have taken a more important place. The concept of cleaning works is the process from sweeping to the disposal of waste. In terms of scope, it is carried out in working environments with very different characteristics such as homes, offices, workplaces, schools, stores, vehicles or hospitals. The increasing population density and the increase in the working area show that there is a direct proportional increase in occupational accidents and nearmisses in cleaning works. With the increasing risks and dangers, the importance of occupational health and safety in cleaning works is increasing.

Occupational accidents are frequently encountered in garbage collection and cleaning work areas. With the scope of the study, literature studies on occupational health and safety in cleaning works, definitions of risk factors, method used, findings, results and recommendations are discussed. The purpose of this research is to determine the dangers and risks that cleaning businesses run by local governments may encounter in their working areas.

While doing the research, field studies and all departments were examined. This study covered employees who may face physical, chemical, ergonomic, mechanical, psychosocial risk factors that have been studied to be determined by observing in the work area. In the examined parts; what kind of dangers there may be, the precautions that can be taken against these dangers, and how to minimize the danger source if the source of danger cannot be eliminated has been determined. As a result 
of these examinations, the legal legislation was taken as a basis and recommendations were made.

L Type Matrix method was used in the risk assessment table prepared. All areas where the employees of the enterprise may encounter a danger are handled separately according to the activity segments. Separating it into activity areas has made it easier to detect dangerous situations and behaviors. Accordingly, the main fields of activity where risk assessment is carried out are divided into five as Business General, Training, Field Studies, Office and Garbage Collection Truck. The risk of a total of 94 potential hazards for 27 subactivity areas under these main activity areas has been evaluated with the L-type matrix method. 25 Unacceptable Risks, 58 Notable Risks and 11 Acceptable Risks have been identified in the enterprise. Risk ratings were high, especially in the workplace, painting works, Welding machine, Power tools, garbage truck activity areas due to insufficient precautions.

In summary, the results and recommendations reached within the scope of the study are listed as items. Low level education of employees poses a major risk. It was observed that the personnel working in the cleaning works encountered cutting and piercing tools while collecting garbage. It has been observed that the personnel who make repetitive movements such as the cleaners are rested at certain intervals. It has been determined that there are various chemicals in the water bottles collected from the environment during the cleaning activities carried out in the working area outside and in the open air, which is mentioned in the definition part of the Thermal Comfort Factors. Since this situation poses a danger to the cleaning personnel, it has been suggested that the personnel be warned verbally by the department supervisors for the use of protective equipment where deemed necessary. Although the necessary precautions have been taken in the enterprise regarding fire and safety, it has been determined that the personnel have behavioral deficiencies. Verbal warnings were given by the department heads. The personnel working in trenching and cleaning works have been observed while working in the field, and the methane and hydrogen sulfide etc. that may come out are observed. Information was given on how to use filter masks against gasses. It has been observed that office personnel do not use computers in accordance with occupational health and safety. 
They were informed about correct sitting, stretching movements, and resting the eyes for certain periods in the study areas. It has been observed that the instructions in which the properties of the chemicals used in all study areas are written are missing. The personnel were informed that personal protective equipment suitable for the work they do should be readily available in the work areas. Partial deficiencies were observed in the emergency assembly areas, and it was recommended to redetermine the emergency assembly areas and conduct exercises with the personnel.

\section{Kaynakça / References}

Aickin, C. (1998). Ergonomic assessment (manual handling) of cleaning work. In: Productivityergonomics And Safety -The Total Package. Proceedings of the International WorkplaceHealth and Safety Forum and the 33rd Ergonomics Society of Australia Conference, Gold Coast, p.1518.

Aickin, C. ve Carrasco, C. (1998). Reduction of manual handling load in cleaning work. Report From Christine Aickin and Associates. WorkCover Authority of NSW, Sydney.

Akgün, A., Soysal, A. ve Demiral, Y. (2010). İzmir Konak Belediyesi temizlik işçilerinde psikososyal etmenlerin iş kazaları üzerine etkileri. TAF Preventive Medicine Bulletin, 9(6), 623-632.

Akkuş, E. (2013). Tehlikeli atık geri kazanım tesisinde iş sağhlğı ve güvenliği. (Yayımlanmamış yüksek lisans tezi). Aksaray Üniversitesi, Fen Bilimleri Enstitüsü, Aksaray.

Akman, Z. (2018). Belediye çalışanlarının iş tatmini üzerine bir araştırma: Erzincan Belediyesi örneği (Yayımlanmamış yüksek lisans tezi). Erzincan Binali Yıldırım Üniversitesi, Sosyal Bilimler Enstitüsü, Erzincan.

Ayan, O. (2017). Kaynaklı imalatta çalışma ortamını ve çalışan sağlığını etkileyen tehlike ve önlemleri. (Yayımlanmamış yüksek lisans tezi). İzmir Katip Çelebi Üniversitesi, Fen Bilimleri Enstitüsü, İzmir.

Ayna, F. G. (2018). İş sağllğg ve güvenliği kavramı ve mobilya sektörü için örnek risk analizi uygulaması. (Yayımlanmamış yüksek lisans tezi). Hacettepe Üniversitesi, Lisansüstü Eğitim Enstitüsü, Ankara. 
Bello, A., Quinn, M.M. ve Perry, M.J. (2009). Characterization of occupational exposures to cleaning products used for common cleaning tasks-a pilot study of hospital cleaners. Environ Health, 8, 11.

Binaların Yangından Korunması Hakkında Yönetmelik, Karar Sayısı: 2007/12937, https://www.resmigazete.gov.tr/eskiler/2007/12/200712192.htm (Erişim tarihi: 25.11.2015).

Brun, E. (2009). The occupational safety and health of cleaning workers, European agency for safety and health at work. https://osha.europa.eu/en/toolsandpublications/publications/literature_revie ws/cleaning_workers_and_OSH (Erişim tarihi: 14.12.2020).

Ceylan, H. ve Başar, O. (2020). Tavas Bahçeköy Olivin Üretim Tesisinde iş güvenliği risk analizi. Teknik Bilimler Dergisi, 10(1), 9-15.

Çeliktaş, B. ve Ünlü, N. (2018). Risk değerlendirme karar matrisi yöntemi kullanarak örnek bir risk değerlendirme raporunun oluşturulması. Jass Studies-The Journal of Academic Social Science Studies, 65, 483-504.

De Vito, G., Molteni, G., Camerino, D., Bordini, L., Molinari, M. ve Capodaglio, P. (2000). Aging and work: Health aspects in cleaners. La Medicina del lavoro, 91(4), 387-402.

Güler, H. E. (2017). Belediyelerde iş sağlı̆̆g ve güvenliği sisteminin oluşturulması süreci-Toroslar Belediyesi Örneği. (Yayımlanmamış yüksek lisans tezi). Mersin Üniversitesi, Fen Bilimleri Enstitüsü, Mersin.

Gündoğdu, D. E. (2016). Temizlik çalışanlarının çalışma koşullarının ve sağlık durumlarmin iş sağhl̆̆̆ ve güvenliği yönünden incelenmesi. (Yayımlanmamış yüksek lisans tezi). Çalışma ve Sosyal Güvenlik Bakanlığı̆ İş Sağllğ 1 ve Güvenliği Genel Müdürlüğü, Ankara.

Güven, N. Y. (2006). Hastanelerde çalı̧̧an kurum ev idaresi personelinin hizmet içi eğitim programının değerlendirmesi. (Yayımlanmamış yüksek lisans tezi). Mersin Üniversitesi, Fen Bilimleri Enstitüsü, Mersin.

İşyerlerinde Acil Durumlar Hakkında Yönetmelik, Resmî Gazete Tarihi: 18.06.2013 Resmî Gazete Sayıs: 28681 https://www.mevzuat.gov.tr/mevzuat?MevzuatNo=18493\&MevzuatTur=7 $\mathcal{E}$ MevzuatTertip=5 (Erişim tarihi: 22.11.2020).

Kol, İ. (2016). İş sağlı̆̆ı ve güvenliğinde operasyonel disiplin. (Yayımlanmamış yüksek lisans tezi). Gedik Üniversitesi, Sosyal Bilimler Enstitüsü, İstanbul.

Koltan, A., Orhon, H. Y., Yılmaz, S., Altay, M., Yılmaz, S. ve Çay, İ. (2015). Risk değerlendirmede kullanılan L Tipi Karar Matrisi yönteminin 
işçi sağlığına uygunluğunun değerlendirilmesi. Mesleki Sağllk ve Güvenlik Dergisi (MSG), 10(38), 38-43.

Kumar, R., Chaikumarn, M. ve Lundberg, J. (2005). Participatory ergonomics and an evaluation of a low-cost improvement effect on cleaners' working posture. International Journal of Occupational Safety and Ergonomics, 11(2), 203-210.

Mazak, M. (2001). Osmanlı'da çevre ve sokak temizliği. İstanbul: İSTAÇ A.Ş. Yayınları.

National Research Council (2007). Scientific review of the proposed risk assessment bulletin from the office of management and budget. Washington, DC: The National Academies Press. https://doi.org/10.17226/11811.

Özcan, Ç. ve Kızıl, M. (2020). İş stres düzeyinin çalışanlarda beslenme durumu, diyet kalitesi ve antropometrik ölçümlere etkisinin değerlendirilmesi. Beslenme ve Diyet Dergisi, 48(3), 56-64.

Özer, T. (2018). 6331 Sayılı İş Sağhlğı ve Güvenliği Kanunun iş kazalarına etkisi:2012 yılı 2016 yılı istatistiksel karşılaştırması. (Yayımlanmamış yüksek lisans tezi). İstanbul Gelişim Üniversitesi, Sosyal Bilimler Enstitüsü, İstanbul.

Özkılıç, Ö. (2005). İş sağhlğı ve güvenliği yönetim sistemleri ve risk değerlendirme metodolojileri. Şehir: TísK Yayınları, s.220.

Paulsen, O.M., Breum, N.O ve Ebbehøj, N. (1995). Collection of domestic waste. Review of occupational health problems and their possible causes. The Science of the Total Environment, 170, 1-19.

Sarilar, A. (2015). Bir gıda işletmesinde iş să̆lı̆̆ı ve güvenliğgi yönünden risk değerlendirmesi. (Yayımlanmamış yüksek lisans tezi). Mersin Üniversitesi, Fen Bilimleri Enstitüsü, Mersin.

SOYKAN, O. (2018). Risk assessment in industrial fishing vessels by L type matrix method and its usability. Ege Journal of Fisheries and Aquatic Sciences, 35(2), 207-217.

Şahin, M. ve Gürcanll, G. E. (2012). Betonarme, çelik ve hafif çelik binalarda iş güvenliği risklerinin karşılaştırmalı analizi. İşçi Sağhlğ̆ ve İş Güvenliği Sempozyumu, Çanakkale, 201-212.

Ünsal, F. (2019). Muğla Sttkı Kocaman Üniversitesi yurt ve öğrenci evleri inşaatınin iş sağhl̆̆̆ ve güvenliğ̈i açısından değerlendirilmesi. (Yayımlanmamış yüksek lisans tezi). Süleyman Demirel Üniversitesi, Fen Bilimleri Enstitüsü, Isparta. 
Woods, V. ve Buckle, P. (2006). Musculoskeletal ill health amongst cleaners and recommendations for work organisational change. International Journal of Industrial Ergonomics, 36(1), 61-72.

Yavuzkan, G., Kaya, K., Yağız, M. C., Erdem, M. ve Acar, I. (2015). Ergonomi risk analizleri yazılımlaştırılması ergonomi-iş sağlığı güvenliği risk haritalandırılması. Mühendislik Bilimleri ve Tasarm Dergisi, 3(3), 603614.

Zock, J. P (2005). World at work:Cleaners. Occupational and Environmental Medicine, 62(8), 581-584.

6331 Sayılı İş Sağlığı ve Güvenliği Kanunu, Kanun numarası:6331, https://www.mevzuat.gov.tr/MevzuatMetin/1.5.6331.pdf (Erişim tarihi: 19.11.2020).

\section{Kaynakça Bilgisi / Citation Information}

Demir, A., Gümüş, M., Yumurtacı Aydoğmuş, H. ve Kamber, E. (2021). Temizlik işleri çalışmalarında risk değerlendirmesi: Alanya Belediyesi örneği. OPUS-Uluslararası Toplum Araştırmaları Dergisi, 18(44), 7855-7882. DOI: 10.26466/opus.917527. 